\title{
The Reproduction of the Red Sea Coral Stylophora pistillata. II. Synchronization in Breeding and Seasonality of Planulae Shedding
}

\author{
B. Rinkevich and Y. Loya \\ Department of Zoology, The George S. Wise Center for Life Sciences, Tel Aviv University, Tel Aviv, Israel
}

\begin{abstract}
Synchronization in breeding and seasonality of planulae siedding of the hermatypic coral Stylophora pistillata were studied in the northern Gulf of Eilat, Red Sea. Gonads were histologically examined every month, for approximately 2 years. Planulae larvae were collected in situ over 5 years. In contrast to the results of Atoda (1947a) in Palao, who claimed lunar periodicity of planulation, no correspondence with lunar periodicity was observed in the population of the Gulf of Eilat. $S$. pistillata has a long period of reproduction lasting approximately 8 months (from December to July). During the reproductive period synchronization in breeding exists in different branches within a single colony. However, no such synchronization has been found among colonies within the population. In a reproductive colony, all polyps on the mid part of a branch contained gonads, while only a few polyps from the tips of the branches contained genital cells. Reproduction in $S$. pistillata begins in colonies of size groups $\overline{\mathrm{r}}=1.51$ to $2.00 \mathrm{~cm}$. More than $50 \%$ of the population was found to be in reproduction in the size groups $\bar{r}=2.01$ to $2.50 \mathrm{~cm}$. In the first year of reproduction, the vast majority of the population contains male gonads only. With an increase in size, there is a tendency of an increase in the percent of hermaphroditic colonies within the population. In the largest colonies $(\bar{r}>5.50 \mathrm{~cm})$ more fernale gonads per polyp are developed compared with smaller size groups $(\bar{r}<5.50 \mathrm{~cm})$. High variability was found in the number of extruded planulae $(24.2 \pm 42.5$ per coral head, per night). From the view of point of reproductive effort, $S$. pistillata exhibits 4 major stages in its life history: very young or non-reproductive colonies, first-year reproductive colonies (mainly males), hermaphroditic mature colonies, and hermaphroditic oldest colonies.

Differences in the life history of the Red Sea and Palao populations and the fact that $S$. pistillata is a brooding species - in contrast to a theoretical expectation of a typical r-strategist - are discussed.
\end{abstract}

\section{INTRODUCTION}

Marshall and Stephenson (1933) stated that their work on the breeding of reef corals must be regarded as a preliminary study since 'it will be clear to anyone familiar with work of this nature that in dealing with a considerable number of species for one year only, a complete picture could not be expected'. This statement reflects the problem of studying life history features of many coral species. Since a great variability exists between different colonies within a population, it is frequently meaningless to draw conclusions without studying large numbers of individuals within a population. We therefore preferred to examine in detail one species only, the hermatypic coral Stylophora pistillata, which is the most abundant scleractinian coral in shallow water along the Gulf of Eilat (Loya, 1976a). Our study on the reproduction of this species is based on continuous observations of more than 500 colonies, for a period of approximately 2 years.
Many of the works concerning reproduction in hermatypic corals deal with the mode and periodicity of shedding planulae. Thus, Harrigan (1972) noted that lunar periodicity of planulation in scleractinian corals has been described for 9 species and found to be absent in 12 .

The present paper examines reproductive synchronization between different branches within a colony, and between different colonies within a population. In addition, it describes the reproductive season, onset of reproduction in young colonies and different reproductive stages within a population.

Since Stylophora pistillata was studied by Atoda (1947a) in Palao, it was of interest to compare our study to his observations. Atoda (1947a) examined lunar periodicity of shedding planulae, the duration of their planktonic period, post larval development, and reported on some general features of the colony and the planula-larva. The differences in some characteristics of the colony and the planula-larva between Palao 
$\left(7.5^{\circ} \mathrm{N}\right)$ and Eilat, Red Sea $\left(30^{\circ} \mathrm{N}\right)$ are discussed in the present work.

Stylophora pistillata has been described as an $\mathrm{r}-$ strategist (Loya, 1976a). Yet, in contrast to the expected features of such a strategy we found that $S$. pistillata broods its eggs until they reach the highly developed planula structure of the Halcampoides stage (Rinkevich and Loya, 1979). This apparent contrast is discussed.

\section{MATERIALS AND METHODS}

Most of the present work was carried out from March 1974 to August 1975 , in a study area located $5 \mathrm{~km}$ south to the Coral Nature Reserve of Eilat, Red Séa. The study area was visited regularly approximately every month. Methods and materials for gonad observations and planulae collection are discussed in the preceeding paper (Rinkevich and Loya, 1979).

In order to examine possible periodicity in planulae shedding by Stylophora pistillata, planulae were collected periodically according to the moon's age, which was divided into nearly 8 equal phases, from new moon to full moon (each phase contains 3 to 4 days, as termed by Atoda, 1947b).

A gonadal index was formulated, which takes into account the number of male and female gonads per polyp and their developmental stage in order to gain quantitative knowledge of the reproductive state of a colony (Table 1 ). The range of the gonadal index is 0 to 3 for either the male or female gonads, hence, the maximum possible gonadal index for a colony is 6 .

Table 1. Stylophora pistillata. A gonadal index for colonies (After Rinkevich and Loya, 1977)

\begin{tabular}{|ccl|}
\hline $\begin{array}{c}\text { Average no. of } \\
\text { male or female } \\
\text { gonads per polyp }\end{array}$ & $\begin{array}{c}\text { Gonadal } \\
\text { index }\end{array}$ & $\begin{array}{l}\text { Colony reproductive } \\
\text { state }\end{array}$ \\
\hline 0.0 & 0.0 & Non-reproductive \\
$0.01-0.50$ & 0.5 & Primordial gonads \\
$0.51-1.00$ & 1.0 & Low \\
$1.01-2.00$ & 2.0 & Intermediate \\
$>2.00$ & 3.0 & High \\
\hline
\end{tabular}

In order to study the reproductive contribution of different parts along a branch of a colony, 8 branches (at least $5 \mathrm{~cm}$ in length) were randomly sampled from different mature colonies. After decalcification, 3 tissue samples were taken from each branch: from the tip, $0.5 \mathrm{~cm}$ below the tip, and from the middle of the branch. Five polyps were examined from each tissue sample. Table 2 indicates that only a few polyps from the tips contained genital cells, while all the polyps
Table 2. Stylophora pistillata. Percentage of polyps containing gonads along different parts of a branch

\begin{tabular}{lccc|}
\hline Location on a branch: & tip & $\begin{array}{c}0.5 \mathrm{~cm} \\
\text { below tip }\end{array}$ & middle \\
\hline $\begin{array}{l}\text { Number of polyps } \\
\text { examined: }\end{array}$ & 40 & 40 & 40 \\
$\begin{array}{l}\text { Percentages of breeding } \\
\text { polyps: }\end{array}$ & 5 & 60 & 100 \\
\hline
\end{tabular}

from the middle of the branches contained gonads. Similarly, Harrigan (1972) reports for Pocillopora damicornis that the mid part of a branch contained most of the planulae produced. Therefore, in order to test for possible synchronization in reproduction, we sampled tissue only from at least $1 \mathrm{~cm}$ below the tips of the branches.

For the study of the settlement and development of Stylophora pistillata, observations were made every month on the rates of settlement of new colonies on artificial substrates, such as PVC pipes and iron frames, installed underwater in front of the M.B.L. at Eilat (Loya, 1976b).

The population studied was divided into size groups using the criteria of the geometric mean radius $(\vec{r})$ of a colony defined by $\bar{r}=$ (L. W. H.) ${ }^{1 / 3} / 2$, as suggested by Loya (1976a), where $\mathrm{L}=$ length, $\mathrm{W}=$ width and $\mathrm{H}=$ height of a given colony.

\section{RESULTS}

\section{Lunar Periodicity and Planulation}

The period of planulation in Stylophora pistillata was continuously studied between 1974 to 1979 . The major problems investigated in this context were whether planulation occurs throughout the year and whether there is any connection between the lunar phases and periodicity of planulation. In this part of the study, the following observations were made: (1) Histological sections of polyps from 147 big $S$. pistillata colonies (6 to 14 colonies, at least $25 \mathrm{~cm}$ in diameter, were randomly chosen every sampling period, Fig. 1, A). (2) Monthly examination for possible appearance of eggs in 4 marked colonies, 3 of which died during the study (Fig. 1, B). (3) Collection of planulae in situ (approximately 100 collection-periods in all moon phases and at least 10 colonies sampled every period). (4) Observations on settlement of new colonies on artificial substrates.

The results presented in Fig. 1 and Table 3 indicate that Stylophora pistillata has a long period of reproduction, lasting approximately 8 months every year, from December to July. 

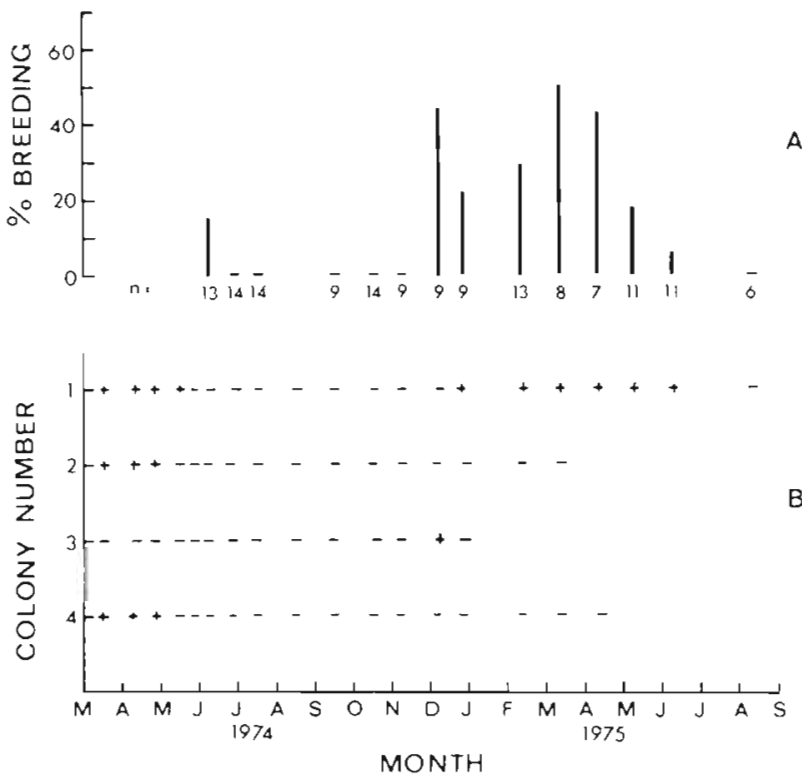

Fig. 1. Stylophora pistillata. Seasonality in reproduction during March 1974 to August 1975. A: Percentages of breeding colonies containing eggs. B: Appearance of eggs within polyps of 4 marked colonies

In contrast to results of Atoda (1947a), no lunar periodicity in planulation of Red Sea Stylophora pistillata larvae was recorded (March 1974 to May 1979). During the reproduction period of $S$. pistillata, planulae were always shed in all 8 moon phases. In the non-breeding period (August to November) extrusion of planulae has never been recorded.

The appearance of new colonies of Stylophora pistillata in the field strengthens these results. Thus, Loya (1976b) described settlement of $S$. pistillata on a PVC pipe across from the MBL at Eilat. The pipe was installed underwater in March 1974 and new colonies were observed on it in January 1975 (the beginning of the next reproductive season). New colonies continued to settle on the pipe until August 1975. No settlement was recorded from August 1975 to January 1976. In January 1976, colonization of new colonies was observed. Observations on settlement of $S$. pistillata planulae on chains of Petri dishes attached underwater to the lagoon's rocks, yielded similar results. Harrigan (1972) suggested that reproduction in a species may have a basic endogenous rhythm controlled by exogenous environmental factors. The results presented in Table 3 support Harrigan's conclusions. For example, the reproductive period of $S$. pistillata in 1976 was from December of the preceding year to June, while in 1977 the reproductive season was from February to July.

\section{Reproduction Within a Single Colony}

In order to study possible synchronization in reproduction between different branches of the same colony, 168 branches were sampled from 17 colonies during March to October 1974 (6 to 11 branches per colony). Female and male gonads in an advanced reproductive state were found in 12 colonies (116 branches). Two colonies (20 branches) contained no genital cells. The latter 14 colonies were sampled during March to June. Three colonies (32 branches) which were sampled in October showed variation in the number of gonads within the same colony. For example, female gonads were found only in part of the branches within the same colony.

In conclusion, there is a marked variation within the reproductive state of a colony in the period of gonadal development (July to December). However, during the period of planulae shedding (December to June) there is a remarkable synchronization in breeding between different branches of the same colony and furthermore, no significant difference exists in the number of gonads found in different branches of the same colony.

Examination of the rate of reproduction in 4 marked colonies sampled every month, revealed successive developmental structures of ovaries and testes from June to December (Fig. 1, B). It is therefore concluded that a single branch sampled from a colony during the reproductive period represents the reproductive state of the entire colony.

\section{Colony Size and Onset of Reproduction}

In order to determine the size in which Stylophora pistillata starts to reproduce, 112 young colonies of different size groups were collected. The sampled col-

Table 3. Stylophora pistillata. Planulae shedding in colonies during 1974 to 1979

\begin{tabular}{|lcccccccccccccc}
\hline Year & Jan & Feb & Mar & Apr & May & Ju & Jul & Aug & Sep & Oct & Nov & Dec \\
\hline 1974 & & & & + & + & + & + & - & - & - & - & - & + \\
1975 & + & + & + & + & + & + & + & - & - & - & + & + \\
1976 & + & + & + & + & + & + & - & - & - & - & - & - \\
1977 & - & + & + & + & + & + & + & - & - & - & - & + \\
1978 & + & + & + & + & + & + & + & - & - & - & - \\
1979 & + & + & + & + & + & + & & & & & \\
\hline
\end{tabular}


onies ranged from a geometric mean radius ( $\bar{r}$ ) of 0.5 to $4.0 \mathrm{~cm}$. Since only 2 colonies were in the size group $\bar{I}=2.51$ to $3.00 \mathrm{~cm}, 9$ colonies with $\bar{r}=3.01$ to $3.50 \mathrm{~cm}$ and 2 colonies with $\vec{r}=3.51$ to $4.00 \mathrm{~cm}$, we joined them into one group (i.e. $r=2.51$ to 4.00 ). Table 4 summarises the percentages of breeding colonies in all size groups. It is shown that reproduction in $S$. pistillata begins when a colony reaches a geometric mean radius of 1.51 to 2.00 (32\% of the colonies in this size group contained gonads), while in the younger colonies $(\vec{T}=0.50$ to 1.51$)$ of 52 examined colonies only 1 was found to contain gonads. In the size groups $\bar{r}=2.01$ to 2.50 , which correspond to 2 -year-old colonies (Loya, in preparation), more than $50 \%$ of the population was found to be in reproduction. This demonstrates one of the r-strategy characteristics in the life history of this species (Loya, 1976a).

Table 5 shows that in the very small size groups (first year of reproduction), the vast majority of the population of Stylophora pistillata contains male gonads only. With an increase in size, there is a tendency of an increase in the percent of hermaphroditic colonies within the population.

\section{Synchronization in Reproduction}

We have shown earlier that synchronization in reproduction exists between different branches of a single colony. However, when the whole population was examined, no synchronization of reproduction was found between different colonies. Within the population the gonadal index (Table 1) varied from 0 to 6 among different colonies. Thus, some colonies contained 5 ova and 5 spermaria per polyp, while others had less than 1 of either gonad, or contained male gonads only. Table 4 further indicates that in all size groups some of the colonies were not in a reproductive state.

There are also differences in the rate of reproduction (Table 6) between intermediate sized colonies ('mature' colonies, $\bar{r}=3.01$ to $5.50 \mathrm{~cm}$ ) and larger sized colonies ('oldest' colonies, $\bar{r}=5.51$ to $8.51 \mathrm{~cm}$ ).
Table 4. Stylophora pistillata. Percent reproduction in a population of different size groups

\begin{tabular}{|lcc|}
\hline$\overline{\mathrm{S}}($ in cm) & No. of colonies & $\begin{array}{c}\% \text { of colonies } \\
\text { in reproduction }\end{array}$ \\
\hline $0.50-1.00$ & 19 & 0.0 \\
$1.01-1.50$ & 33 & 3.0 \\
$1.51-2.00$ & 25 & 32.0 \\
$2.01-2.50$ & 22 & 54.5 \\
$2.51-4.00$ & 13 & 69.2 \\
$4.01-4.50$ & 10 & 90.0 \\
$4.51-5.00$ & 12 & 83.3 \\
$5.01-5.50$ & 11 & 81.8 \\
$5.51-6.00$ & 13 & 92.3 \\
$6.01-8.50$ & 14 & 92.9 \\
\end{tabular}

While no significant differences $(p>0.05)$ were found between the two size groups in the number of colonies with female gonadal index of 1 and 2, a significantly larger number of colonies with gonadal index of 3 were found in the oldest size group ( $p<0.01$, Fisher's exact test, Sokal and Rohlf, 1969). In conclusion, in larger (older) colonies more female gonads per polyp are developed. These results support the conclusion of Gadgil and Bossert (1970), that the value of reproductive effort increases with age in the case of repeated reproducers. That is, from the view point of reproductive effort, Stylophora pistillata exhibits 4 major stages in its life history: Very young or non-reproducting colonies, first-year reproductive colonies (mainly males), hermaphroditic mature colonies, and hermaphroditic oldest colonies.

\section{Planulae}

In this part of the study plankton nets were placed over 102 colonies (Fig. 2), in order to capture extruded planulae. The average number of planulae released per coral head was found to be $24.2 \pm 42.5$. These data are similar to Harrigan's (1972) results on Pocillopora damicomis in Hawaii. She received a mean planulaproduction of $28 \pm 123$ from 48 coral heads maintained in the laboratory for $24 \mathrm{~h}$.

Table 5. Stylophora pistillata. Percent of male and hermaphroditic colonies in a population Parentheses: numbers of colonies studied in a given size group

\begin{tabular}{|c|c|c|c|c|}
\hline$\overline{\mathrm{r}}(\mathrm{in} \mathrm{cm})$ & $\begin{array}{l}\text { No. of breeding } \\
\text { colonies }\end{array}$ & $\begin{array}{l}\text { No. of colonies } \\
\text { containing male } \\
\text { gonads only }\end{array}$ & $\begin{array}{l}\text { No. of hermaph- } \\
\text { roditic colonies }\end{array}$ & $\begin{array}{l}\% \text { of hermaph- } \\
\text { roditic colonies }\end{array}$ \\
\hline $1.01-1.50$ & $1(33)$ & 1 & 0 & 0 \\
\hline $1.51-2.00$ & $8(25)$ & 7 & 1 & 12.5 \\
\hline $2.01-2.50$ & $12(22)$ & 8 & 4 & 33.3 \\
\hline $2.51-4.00$ & $9(13)$ & 2 & 7 & 77.7 \\
\hline
\end{tabular}


Table 6. Stylophora pistillata. Female gonadal-index in intermediate and large-sized colonies. Parentheses: number of colonies in reproductive state

\begin{tabular}{|c|c|c|c|c|}
\hline \multirow[t]{2}{*}{$\bar{r}($ in $\mathrm{cm})$} & \multirow{2}{*}{$\begin{array}{l}\text { No. of her- } \\
\text { maphroditic } \\
\text { colonies }\end{array}$} & \multicolumn{3}{|c|}{$\begin{array}{l}\text { Percent colonies } \\
\text { with gonadal index }\end{array}$} \\
\hline & & 1 & 2 & 3 \\
\hline $3.01-5.50$ & $24(35)$ & 50.0 & 45.8 & 4.2 \\
\hline $5.51-8.50$ & $20(25)$ & 25.0 & 20.0 & 55.0 \\
\hline
\end{tabular}

As found for the gonads, there is a great variability between different colonies in the number of extruded planulae. Fig. 2 indicates that 13 colonies $(12.7 \%)$ did not release any planulae. These colonies might have not been in reproductive state, or could have been male colonies, or simply did not shed any planulae during the particular night that they were sampled. It should be emphasized that only mature planulae were counted, while the youngest planulae have not been taken into consideration (because of uncertainties concerning their identity). For example, after rinsing a plankton net within a bucket containing filtered sea water, a total of 117 planulae were counted and removed from the bucket. After $24 \mathrm{~h}$, additional 115 planulae developed in the left-over water of the bucket. This result suggests that our record for the average number of expelled planulae per coral head is a minimum estimate and it is very likely that more planulae are produced.

\section{DISCUSSION}

Stylophora pistillata is among the very few coral species that were studied in different geographical regions. Atoda (1947a) studied the planula and the post larval development of this species in Palao $\left(7.5^{\circ} \mathrm{N}\right)$. We studied different life history characteristics of $S$. pistillata at Eilat (approximately $30^{\circ} \mathrm{N}$ ). It is of interest to compare the differences reported on some characteristics of the colony and planula of this species (Table 7) at Eilat (Rinkevich and Loya, 1979, and this work) and Palao (Atoda, 1947a).

As shown in Table 7, a marked difference exists in various aspects of the life history of Stylophora pistillata at Eilat and Palao. Similar variations were reported for other corals and sea-anemones: Marshall and Stephenson (1933) working at the Great Barrier Reef $\left(16.5^{\circ} \mathrm{S}\right)$ reportet that Pocillopora bulbosa (now called P. damicornis, Veron and Pichon, 1976) planulated during new moon in December to April (summer and early winter) but during July to August (winter) expelled planulae at about the time of full moon. There was a transition period in May to June. In P. damicornis from Palao $\left(7.5^{\circ} \mathrm{N}\right)$ Atoda $(1947 \mathrm{~b})$ found also

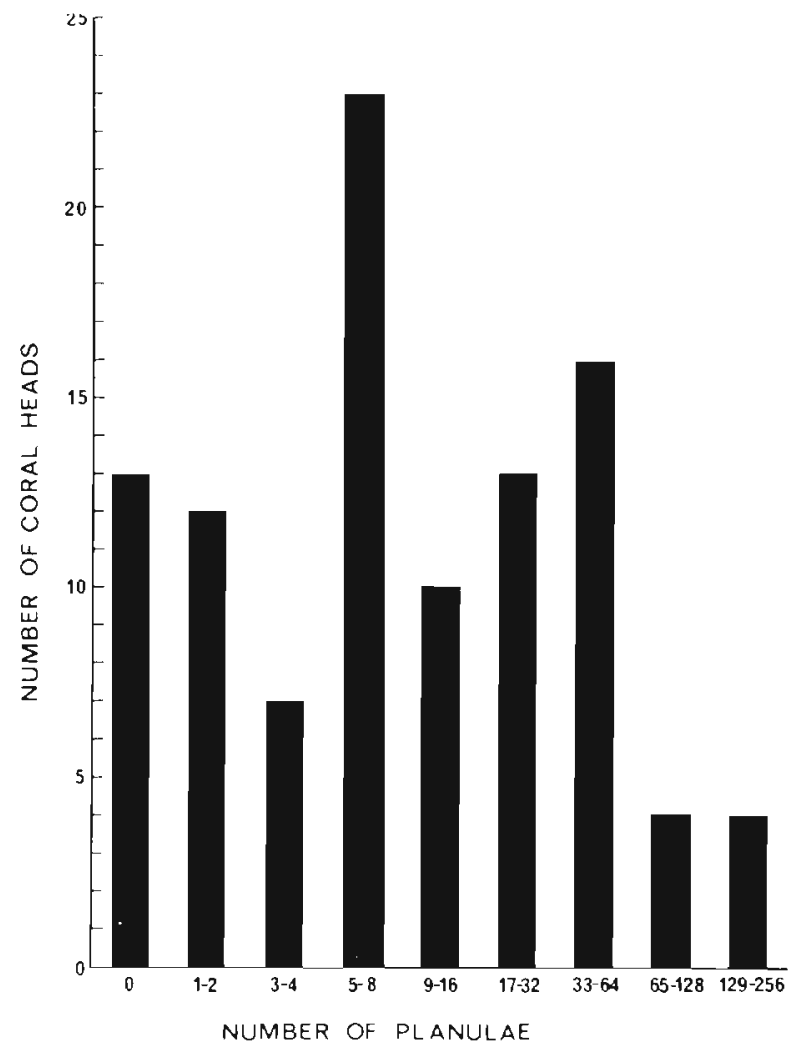

Fig. 2. Stylophora pistillata. Number of planulae extruded by colonies

planulae liberation throughout the whole year in accordance with lumar periodicity, but planulation there started several days before new moon, reached a maximum at new moon and terminated several days later. At full moon, planulation was not recorded. Similar results have been reported by Stimson (1978) for $P$. damicomis from Enewetak (12.5 N). Harrigan (1972) found that $P$. damicornis in Hawaii $\left(21.5^{\circ} \mathrm{N}\right)$ released planulae throughout the year at all moon phases. However, significantly larger numbers of planulae were shed during the last quarter (from full moon to new moon) than during the other 3 moon phases. In the Great Barrier Reef, Australia, planulae of P. damicornis were reported to float about 7 days (Stephenson, 1931), in Palao up to 9 days (Atoda, 1947b), in Hawaii up to 18 days (Harrigan, 1972). This example also indicates that the same coral species reveals changes in its life history in different geographical areas.

Rossi (1975) worked on the reproduction of the seaanemone Cereus pedunculatus at 4 different localities in Italy. He found different modes of reproduction and types of sexuality, as well as some morphological differences (size, colour, tentacle number) in populations from different sites. The populations of 2 shallowwater localities are parthenogenetic and viviparous, while in a third locality the population is herma- 
phroditic and viviparous. The fourth population sampled at 10 to $15 \mathrm{~m}$ depth (an area with greater stability of temperature, salinity and water movement) is oviparous and has a gonochorist form.

Loya (1976a) described Stylophora pistillata from the Red Sea as an r-strategist, since it exhibits success in colonizing unpredictable reef habitats, rapid development, great population turnover, early reproduction, high $r_{\text {max }}$ small colony size, short life span, densityindependent mortality (often catastrophic), wide dispersal gradient and poor competitive ability.

Two theoretical difficulties arise from our studies on Stylophora pistillata: The first concerns the differences in the life history of the Red Sea and the Palao populations, the second is the fact that $S$. pistillata is a brooding species in contrast to a theoretical assumption which expects a typical $r$-strategist to be a broodcasting species (see review by Stearns, 1976). Moreover, many of the planulae produced are of the highest developmental stage reported in scleractinian corals.

Environmental conditions seem to be much more constant and predictable in tropical Palao $\left(7.5^{\circ} \mathrm{N}\right)$ than in Eilat $\left(30^{\circ} \mathrm{N}\right)$. Harrigan (1972) in her summary of annual temperatures in different areas indicated that in Palao the annual water temperature ranges from $27^{\circ}$ to $28^{\circ} \mathrm{C}$. In her extensive review of our knowledge on planulation and periodicity of coral species she pointed out that only in the most constant equatorial waters seasonal breeding is so far undiscovered. In the northern part of the Gulf of Eilat the annual water temperatures range from $20^{\circ}$ to $26^{\circ} \mathrm{C}$. Studying reproductive periodicity in sea-urchins, Pearse (1970) con- cluded that in populations of Diadema setosum a gradient in reproductive activity occurs. In populations progressively further away from the equator than about $10^{\circ}$ to $15^{\circ}$ latitude, spawning is restricted more and more to the summer, whereas in populations near the equator spawning probably occurs throughout the year (Pearse, 1968)

This ties in well with the differences found in the reproductive periodicity of Stylophora pistillata in Palao (Atoda, 1947a) and in the Gulf of Eilat. As originally defined, the $r$ and $K$ selection concepts postulated that alternative genotypes within a species possessed somewhat divergent life history characteristics (MacArthur and Wilson, 1967). If one visualizes an $r-K$ continuum of a particular species (Pianka, 1970), we would expect that the same coral species would be closer to the $r$-end point, when found further away from the equator. Some characteristics of the life history of $S$. pistillata in the Gulf of Eilat compared to Palao support this assertion (Table 7).

The highly developed planula of Stylophora pistillata (Halcampoides stage) stands in contrast to the expected characteristics of an $r$-strategist. However, as emphasized by Pianka (1970), no organism is completely ' $r$-selected' or completely ' $K$-selected', but all must reach some compromise between the two extrems. Furthermore, within marine invertebrates, egg-protection mechanisms become increasingly common as one moves towards the poles from the equator (Thorson, 1946), suggesting that these adaptations are not so unusual.

Some examples for deviations in reproductive

Table 7. Stylophora pistillata. Differences in some characteristics of colony and planula at Eilat and Palao

\begin{tabular}{|c|c|c|}
\hline & Eilat & Palao \\
\hline \multicolumn{3}{|l|}{ Colony } \\
\hline Local abundance & $\begin{array}{l}\text { Most abundant species in shallow } \\
\text { waters }\end{array}$ & $\begin{array}{l}\text { Uncommon, no aggregation recorded } \\
\text { in one habitat }\end{array}$ \\
\hline Color & $\begin{array}{l}\text { Yellow, brownish-green, pink-purp- } \\
\text { le, some are fluorescentic }\end{array}$ & Dark brown or brownish-yellow \\
\hline \multicolumn{3}{|l|}{ Planula-larva } \\
\hline Planulation & Seasonal, no lunar periodicity & $\begin{array}{l}\text { During the whole year, in correspon- } \\
\text { dence with lunar periodicity }\end{array}$ \\
\hline Developmental stage in shedding & $\begin{array}{l}\text { Great variability, from rudimentary } \\
\text { mesenteries to six pairs of complete } \\
\text { mesenteries (Halcampoides stage) }\end{array}$ & $\begin{array}{l}\text { Three couples of complete mesente- } \\
\text { ries recorded }\end{array}$ \\
\hline Special organs & 'Filaments' and 'nodules' & Not recorded \\
\hline Fluorescence & Found in all developed planulae & Not recorded \\
\hline Expelled materials from oral pole & $\begin{array}{l}\text { Abundant, especially in stress condi- } \\
\text { tions }\end{array}$ & Not recorded \\
\hline Free swimming period & $\begin{array}{l}\text { Most of the well-developed planulae } \\
\text { (Halcampoides stage) settled imme- } \\
\text { diately after shedding. Great variabi- } \\
\text { lity in settlement period of less devel- } \\
\text { oped planulae (may reach a maxi- } \\
\text { mum of } 35 \text { days) }\end{array}$ & $\begin{array}{l}\text { Sixty percent of the planulae settled } \\
\text { within } 6 \text { days. Planulae which failed } \\
\text { to settle died } 10 \text { days after shedding. }\end{array}$ \\
\hline
\end{tabular}


strategy from the framework of the $r$ - $K$ selection concepts are given below. Hartnoll (1977) described different reproductive strategies in two species of $\mathrm{AlCy}$ onium which co-exist in the same area. Thus, although A. hibernicum exhibits mainly r-characteristics when compared to $A$. digitatum, it is a brooding species, while $A$. digitatum has external fertilization. Menge (1974) describes 2 competing species of sea star, of which the larger species is a $K$-strategist in many of its life history characteristics, whereas the smaller exhibits $r$-strategy characteristics. However, the smaller species was found to brood few and large eggs, while the larger species broodcasts many small eggs. Grassle and Grassle (1974) described the life histories of 6 opportunistic marine polychaetes in the benthos of West Falmouth, Massachusetts. They found that the most opportunistic species (Capitella capitata) broods its eggs. Moreover, in contradiction to the generalization that $r$-selected species have a single reproductive period (Pianka, 1970) the adult of C. capitata can produce several broods. Wilbur et al. (1974) attempted to explain life histories of well studied species from the literature which failed to be described within the framework of the $r-K$ selection concept. They suggested that considerations of many environmental dimensions seem essential to provide complete understanding of the evolution of life histories. Thus, the causal interpretation of life history characteristics may be due to research limitation. Instead of coining new terms, they suggested additional ecological dimensions, such as environmental predictability and relative trophic position of a species that also seem to be important in the evolution of life histories.

It is possible that the evolvement of brooding and shedding of highly developed planulae in Stylophora pistillata is a result of intense competitive interactions with other opportunistic species (see below) and the possibility that energy for reproduction is not a limiting factor in this species.

Food does not seem to be a limiting factor for hermatypic corals, since there is a variety of ways corals can satisfy their daily energy requirements: Zooplankton predation (Yonge, 1931), assimilation of translocated products from zooxanthellae (Muscatine, 1973), suspension feeding (Lewis, 1976), bacterial assimilation (DiSalvo, 1971), uptake of dissolved organic materials (Stephens, 1962), as well as dissolved inorganic materials (D'Elia, 1977). Stylophora pistillata is a branching smallpolyped coral with high surface/volume ratio. According to Porter (1976), such a species is expected to be almost independent of zooplankton feeding and is probably capable of satisfying most of its daily carbon requirements from the translocated products of its zooxanthellae.

There is general agreement between investigators that space for settlement is a major limiting resource on coral reefs, for which a high variety of sessile organisms are competing. Many of such organisms may be characterized as closer to the $r$-endpoint of the ' $r$ - $K$ continuum' (Pianka, 1970), when compared to $S$. pistillata. At the Gulf of Eilat, algae and soft corals are the major competitors for space with hermatypic corals (Benayahu and Loya, 1977). They suggested that space utilization by stony corals, soft corals and algae might largely be dependent on competition, predation and grazing pressure. Preliminary experiments of colonization of benthic organisms on artificial substrates at the coral reef of Eilat indicate that turf algae are very rapidly covering new available space (Benayahu, personal communication). In such conditions it is advantageous for an $r$-strategist coral (such as S. pistillata) to channel energy into the production of a highly developed planulae rather than producing masses of less developed larvae. In view of the intense competition for space with other organisms such planulae have much better chances of survival and successful settlement.

Acknowledgements. We are grateful to Prof. L. Fishelson for his help and advice during this study. Appreciation is extended to the staff members of the M.B.L. at Eilat for hospitality and facilities. We are obliged to Y. Benyahu and Y Shlesinger for their great help in the field.

This research was supported by an $\mathrm{M}$. Sc. fellowship to B. Rinkevich by the Levi Eshkol Fund (Israeli Council for Research and Development) and by a research grant to $Y$. Loya by the United States-Israel Binational Science Foundation (BSF) Jerusalem, Israel

\section{LITERATURE CITED}

Atoda, K. (1947a). The larva and post larval development of some reef building corals. II. Stylophora pistillata (Esper). Sci. Rep. Tôhoku Univ. (4th Ser.), 18, 48-64.

Atoda, K. (1947b). The larva and post larval development of some reef building corals. I. Pocillopora damicornis cespitosa (Dana). Sci. Rep. Tónoku Univ. (4th Ser.), 18, 24-47

Benayahu, Y and Loya, Y. (1977). Space partitioning by stony corals, soft corals and benthic algae on the coral reefs of the northern Gulf of Eilat (Red Sea). Helgoländer wiss. Meeresunters., 30, 362-382

D'Elia, C. F. (1977). The uptake and release of dissolved phosphorus by reef corals. Limnol. Oceanogr., 22, 301-315.

DiSalvo, L. H. (1971). Ingestion and assimilation of bacterial by two scleractinian coral species. In $H$. M. Lenhoff, L. Muscatine and L. V. Davis (Eds), Experimental Coelenterate Biology. University Hawaii Press, Honolulu. pp. 129-135.

Gadgil, M. and Bossert, W. H. (1970). Life historical consequences of natural selection. Am. Nat. 104, 1-24.

Grassle, J. F. and Grassle, J. P. (1974). Opportunistic life histories and genetic systems in marine benthic polychaetes. J. mar. Res., 32, 253-284. 
Harrigan, J. F. (1972). The planula larva of Pocillopora damicornis: Lunar periodicity of swarming and substratum selection behavior $\mathrm{Ph}$. D. thesis, University of Hawaii

Hartnoll, R. G. (1977). Reproductive strategy in two British species of Alcyonium. In B. F. Keegan, P. O. Ceidigh and P. J. S. Boaden (Eds), Biology of Benthic Organisms Pergamon Press, New York. pp. 321-328.

Lewis, J. B. (1976). Experimental tests of suspension feeding in Atlantic reef corals. Mar. Biol., 36, 147-150.

Loya, Y. (1976a). The Red Sea coral Stylophora pistillata is an I strategist. Nature, Lond., 259, 478-480.

Loya, Y (1976b). Settlement, mortality and recruitment of a Red Sea scleractinian coral population. In G. O. Mackie (Ed.), Coelenterate Ecology and Behavior. Plenum Press, New York. pp. 89-100.

MacArthur, R. H. and Wilson E. O. (1967). The Theory of Island Biogeography, Princeton University Press, Princeton.

Marshall, S. M. and Stephenson, T. A. (1933). The breeding of reef animals. Part I. The corals. Scient. Rep. Gt Barrier Reef Exped., 3, 219-245

Menge, B. A. (1974). Effect of wave action and competition on brooding and reproductive effort in the sea star Leptasterias hexactis. Ecology, 55, 84-93

Muscatine, L. (1973). Nutritions of corals. In O. A. Jones and R. Endean (Eds), Biology and Geology of Coral Reefs, 2 Biology, Vol. 1. Academic Press, New York. pp. 77-115

Pearse, J. S. (1968). Patterns of reproduction in four species of Indo-Pacific echinoderms. Proc. Indian Acad. Sci. (Sect. B), 67, 247-267

Pearse, J. S. (1970). Reproductive periodicities of Indo-Pacific invertebrates in the Gulf of Suez. III. The echinoid Diadema setosum (Leske). Bull. mar. Sci, 20,697-720.

Pianka, E. R. (1970). On $\mathrm{r}$ and $\mathrm{K}$ selection. Am. Nat., 104, $592-597$

Porter, J. W. (1976). Autotrophy, Heterotrophy and resource partitioning in Caribbean reef-building corals. Am. Nat., $110,731-742$.

This paper was submitted to the editor; it was accepted for printing on May 29, 1979
Rinkevich, B. and Loya, Y (1977). Harmful effects of chronic oil pollution on a Red Sea scleractinian coral population. In Proceedings of the 3rd International Coral Reef Symposium, Miami, Florida, 2 (Geology), 586-591.

Rinkevich, B. and Loya, Y. (1979). The reproduction of the Red Sea coral Stylophora pistillata. I. Gonads and planulae Mar. Ecol. Prog. Ser., 1, 133-144.

Rossi, L. (1975). Sexual races in Cereus pedunculatus (Boad.). Pubbl. Staz. zool. Napoli, 39 (Suppl.), 462-470.

Sokal, R. R. and Rohlf, F. J. (1976). Biometry, W. H. Freeman San Francisco.

Stearns, S. C. (1976). Life history tactics: A review of the ideas. Q. Rev. Biol., 51, 3-47.

Stephens, G. C. (1962). Uptake of organic material by aquatic invertebrates. I. Uptake of glucose by the solitary coral Fungia scutaria. Biol. Bull. mar. biol. Lab., Woods Hole, $123,648-659$

Stephenson, T A. (1931). Development and the formation of colonies in Pocillopora and Porites. Scient. Rep. Gt Barrier Reef Exped. 3, 113-134.

Stimson, J. S. (1978). Mode and timing of reproduction in some common hermatypic corals of Hawaii and Enewetak. Mar. Biol., 48, 173-184

Thorson, G. (1946). Reproductive and larval development of Dannish marine bottom invertebrates, with special reference to planktonic larvae in the sound (Oresund). Meddr Kommn Danm. Fisk.-og Havunders. (Ser. Plankton), 4, $1-523$.

Veron, J. E. and Pichon, M. (1976). Scleractinia of Eastern Australia. Part 1. Monograph Ser. Aust. Inst. Mar. Sci., 1, $1-86$.

Wilbur, H. M., Tinkle, D. W. and Collins, J. P. (1974). Environmental certainty, trophic level, and resource availability in life history evolution. Am. Nat., 108, 805-817.

Yonge, C. M. (1931). Studies on the physiology of corals. I. Feeding mechanisms and food. Scient. Rep. Gt Barrier Reef Exped., 1, 14-57. 